\title{
Thorium Fission and Fission-Fusion Fuel Cycle
}

\author{
Magdi Ragheb \\ Department of Nuclear, Plasma and Radiological Engineering \\ University of Illinois at Urbana-Champaign \\ 216 Talbot Laboratory, Urbana, Illinois \\ USA
}

\section{Introduction}

With the present-day availability of fissile $\mathrm{U}^{235}$ and $\mathrm{Pu}^{239}$, as well as fusion and accelerator neutron sources, a fresh look at the Thorium-U233 fuel cycle is warranted. Thorium, as an unexploited energy resource, is about four times more abundant than uranium in the Earth's crust and presents a more abundant fuel resource as shown in Table 1.

\begin{tabular}{|c|c|c|}
\hline Element & Symbol & $\begin{array}{l}\text { Abundance } \\
\text { [gms / ton] }\end{array}$ \\
\hline Lead & $\mathrm{Pb}$ & 16 \\
\hline Gallium & $\mathrm{Ga}$ & 15 \\
\hline Thorium & Th & 10 \\
\hline Samarium & Sm & 7 \\
\hline Gadolinium & $\mathrm{Gd}$ & 6 \\
\hline Praseodymium & $\operatorname{Pr}$ & 6 \\
\hline Boron & B & 3 \\
\hline Bromine & $\mathrm{Br}$ & 3 \\
\hline Uranium & $\mathbf{U}$ & 2.5 \\
\hline Beryllium & $\mathrm{Be}$ & 2 \\
\hline Tin & Sn & 1.5 \\
\hline Tungsten & W & 1 \\
\hline Molybdenum & Mo & 1 \\
\hline Mercury & $\mathrm{Hg}$ & 0.2 \\
\hline Silver & $\mathrm{Ag}$ & 0.1 \\
\hline Uranium $^{235}$ & $\mathbf{U}^{235}$ & 0.018 \\
\hline Platinum & $\mathrm{Pt}$ & 0.005 \\
\hline Gold & $\mathrm{Au}$ & 0.02 \\
\hline
\end{tabular}

Table 1. Relative abundances of some elements in the Earth's crust. 


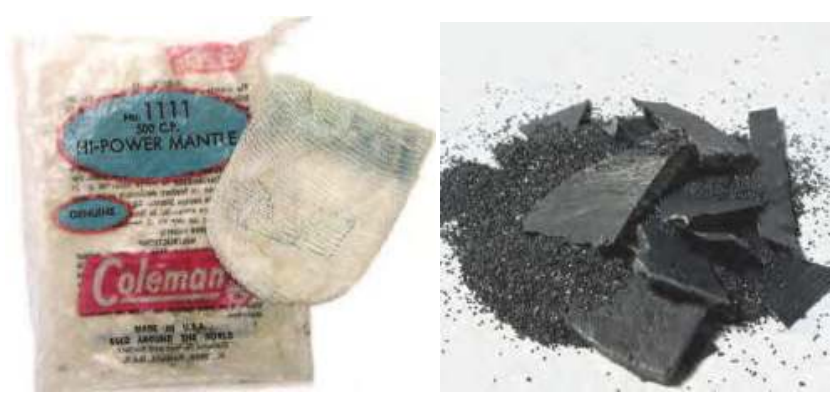

Fig. 1. Thorium dioxide with 1 percent cerium oxide impregnated fabric, Welsbach incandescent gas mantles (left) and $\mathrm{ThO}_{2}$ flakes (right). Yttrium compounds now substitute for Th in mantles.

\section{Properties of thorium}

Thorium (Th) is named after Thor, the Scandinavian god of war. It occurs in nature in the form of a single isotope: $\mathrm{Th}^{232}$. Twelve artificial isotopes are known for Th. It occurs in Thorite, $(\mathrm{Th}, \mathrm{U}) \mathrm{SiO}_{4}$ and Thorianite $\left(\mathrm{ThO}_{2}+\mathrm{UO}_{2}\right)$. It is four times as abundant as uranium and is slightly less abundant than lead.

It can be commercially extracted from the Monazite placer deposit mineral containing 3-22 percent $\mathrm{ThO}_{2}$ with other rare earth elements or lanthanides. Its large abundance makes it a valuable resource for electrical energy generation with supplies exceeding both coal and uranium combined. This would depend on breeding of the fissile isotope $\mathrm{U}^{233}$ from thorium according to the breeding reactions:

$$
\begin{gathered}
{ }_{0} \mathrm{n}^{1}+{ }_{90} \mathrm{Th}^{232} \rightarrow{ }_{90} \mathrm{Th}^{233}+\gamma \\
{ }_{90} \mathrm{Th}^{233} \rightarrow{ }_{91} \mathrm{~Pa}^{233}+{ }_{-1} \mathrm{e}^{0}+v^{*}+\gamma \\
{ }_{91} \mathrm{~Pa}^{233} \rightarrow{ }_{92} \mathrm{U}^{233}+{ }_{-1} \mathrm{e}^{0}+v^{*}+\gamma \\
{ }_{0} \mathrm{n}^{1}+{ }_{90} \mathrm{Th}^{232} \rightarrow{ }_{92} \mathrm{U}^{233}+2_{-1} \mathrm{e}^{0}+2 v^{*}+3 \gamma
\end{gathered}
$$

Together with uranium, its radioactive decay chain leads to the stable $\mathrm{Pb}^{208}$ lead isotope with a half-life of $1.4 \times 10^{10}$ years for $\mathrm{Th}^{232}$. It contributes to the internal heat generation in the Earth, together with other radioactive elements such as $\mathrm{U}$ and $\mathrm{K}^{40}$.

As $\mathrm{Th}^{232}$ decays into the stable $\mathrm{Pb}^{208}$ isotope, radon ${ }^{220}$ or thoron forms in the decay chain. $\mathrm{Rn}^{220}$ has a low boiling point and exists in gaseous form at room temperature. It poses a radiation hazard through its own daughter nuclei and requires adequate ventilation in underground mining. Radon tests are needed to check for its presence in new homes that are possibly built on rocks like granite or sediments like shale or phosphate rock containing significant amounts of thorium. Adequate ventilation of homes that are over-insulated becomes a design consideration in this case.

Thorium, in the metallic form, can be produced by reduction of $\mathrm{ThO}_{2}$ using calcium or magnesium. It can also be produced by electrolysis of anhydrous thorium chloride in a fused mixture of $\mathrm{Na}$ and $\mathrm{K}$ chlorides, by calcium reduction of Th tetrachloride mixed with anhydrous zinc chloride, and by reduction with an alkali metal of Th tetrachloride. 
Thorium is the second member of the actinides series in the periodic table of the elements. When pure, it is soft and ductile, can be cold-rolled and drawn and it is a silvery white metal retaining its luster in air for several months. If contaminated by the oxide, it tarnishes in air into a gray then black color oxide (Fig. 1).

Thorium oxide has the highest melting temperature of all the oxides at 3,300 degrees $\mathrm{C}$. Just a few other elements and compounds have a higher melting point such as tungsten and tantalum carbide. Water attacks it slowly, and acids do not attack it except for hydrochloric acid.

Thorium in the powder form is pyrophyric and can burn in air with a bright white light. In portable gas lights the Welsbach mantle is prepared with $\mathrm{ThO}_{2}$ with 1 percent cerium oxide and other ingredients (Fig. 1).

As an alloying element in magnesium, it gives high strength and creep resistance at high temperatures.

Tungsten wire and electrodes used in electrical and electronic equipment such as electron guns in x-ray tubes or video screens are coated with Th due to its low work function and associated high electron emission. Its oxide is used to control the grain size of tungsten used in light bulbs and in high temperature laboratory crucibles.

Glasses for lenses in cameras and scientific instruments are doped with Th to give them a high refractive index and low dispersion of light.

In the petroleum industry, it is used as a catalyst in the conversion of ammonia to nitric acid, in oil cracking, and in the production of sulfuric acid.

\section{Advantages of the thorium fuel cycle}

The following advantages of the thorium fuel cycle over the $\mathrm{U}^{235}-\mathrm{Pu}^{239}$ fuel cycle have been suggested:

1. Breeding is possible in both the thermal and fast parts of the neutron spectrum with a regeneration factor of $\eta>2$.

2. Expanded nuclear fuel resources due to the higher abundance of the fertile $\mathrm{Th}^{232}$ than $\mathrm{U}^{238}$. The USA resources in the state of Idaho are estimated to reach 600,000 tons of 30 percent of Th oxides. The probable reserves amount to 1.5 million tons. There exists about 3,000 tons of already milled thorium in a USA strategic stockpile stored in the state of Nevada.

3. Lower nuclear proliferation concerns due to the reduced limited needs for enrichment of the $\mathrm{U}^{235}$ isotope that is needed for starting up the fission cycle and can then be later replaced by the bred $U^{233}$. The fission-fusion hybrid totally eliminates that need (Bethe, 1978). An attempted $U^{233}$ weapon test is rumored to have evolved into a fizzle because of the presence of the $\mathrm{U}^{232}$ isotope contaminant concentration and its daughter products could not be reduced to a practical level.

4. A superior system of handling fission product wastes than other nuclear technologies and a much lower production of the long-lived transuranic elements as waste. One ton of natural $\mathrm{Th}^{232}$, not requiring enrichment, is needed to power a 1,000 MWe reactor per year compared with about 33 tons of uranium solid fuel to produce the same amount of power. Thorium would be first purified then converted into a fluoride. The same initial fuel loading of one ton/year is discharged primarily as fission products to be disposed of for the fission thorium cycle.

5. Ease of separation of the lower volume and short lived fission products for eventual disposal. 


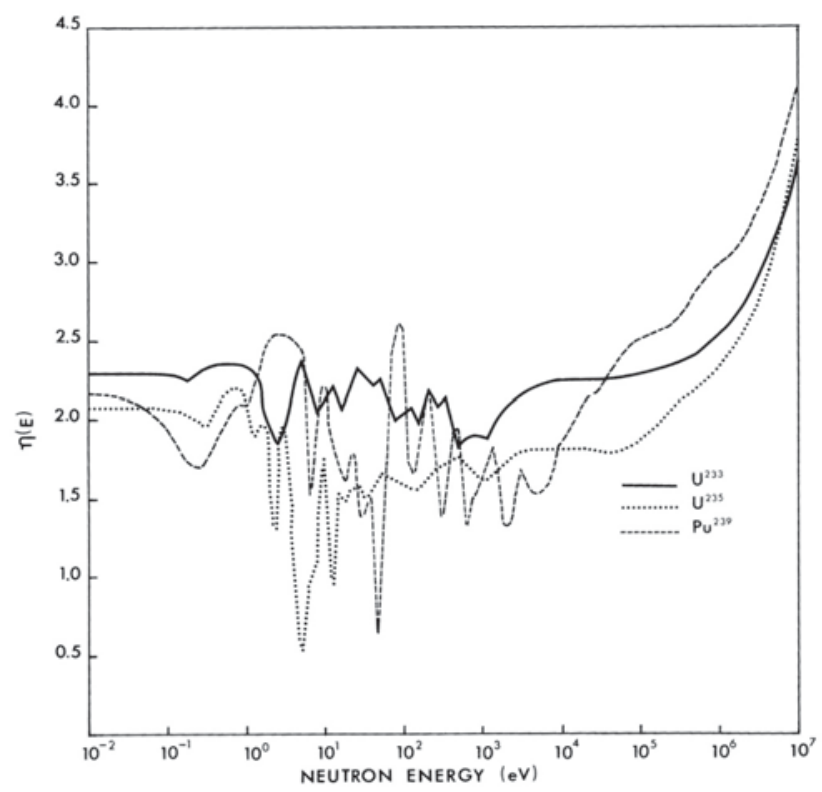

Fig. 2. Regeneration factor as a function of neutron energy for the different fissile isotopes.

6. Higher fuel burnup and fuel utilization than the $\mathrm{U}^{235}-\mathrm{Pu}^{239}$ cycle.

7. Enhanced nuclear safety associated with better temperature and void reactivity coefficients and lower excess reactivity in the core. Upon being drained from its reactor vessel, a thorium molten salt would solidify shutting down the chain reaction,

8. With a tailored breeding ratio of unity, a fission thorium fueled reactor can generate its own fuel, after a small amount of fissile fuel is used as an initial loading.

9. The operation at high temperature implies higher thermal efficiency with a Brayton gas turbine cycle (thermal efficiency around 40-50 percent) instead of a Joule or Rankine steam cycle (thermal efficiency around 33 percent), and lower waste heat that can be used for process heat for hydrogen production, sea water desalination or space heating. An open air cooled cycle can be contemplated eliminating the need for cooling water and the associated heat exchange equipment in arid areas of the world (Fig. 3.).

10. A thorium cycle for base-load electrical operation would provide a perfect match to peak-load cycle wind turbines generation. The produced wind energy can be stored as compressed air which would be used to cool a thorium open cycle reactor, substantially increasing its thermal efficiency, yet not requiring a water supply for cooling.

11. The unit powers are scalable over a wide range for different applications such as process heat or electrical production. Small units of 100 MWe of capacity each can be designed, built and combined for larger power needs.

12. Operation at atmospheric pressure for a molten salt as a coolant without pressurization implies the use of standard equipment with a lower cost than the equipment operated at a 1,000-2,000 psi high pressure in the Light Water Reactor (LWRs) cycle. Depressurization would cause the pressurized water coolant to flash into steam and a loss of coolant. 
13. In uranium-fuelled thermal reactors, without breeding, only 0.72 percent or $1 / 139$ of the uranium is burned as $\mathrm{U} 235$. If we assume that about 40 percent of the thorium can be converted into $U^{233}$ then fissionned, this would lead to an energy efficiency ratio of 139 $x 0.40=55.6$ or 5,560 percent more efficient use of the available resource compared with $\mathrm{U} 235$.

14. Operational experience exists from the Molten Salt reactor experiment (MSRE) at Oak Ridge National Laboratory (ORNL), Tennessee. A thorium fluoride salt was not corrosive to the nickel alloy: Hastelloy-N. Corrosion was caused only from tellurium, a fission product (Ragheb et. al., 1980).

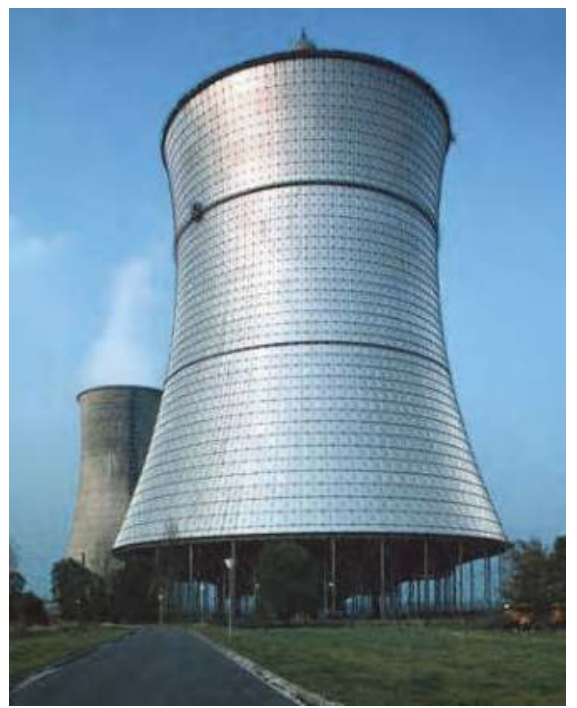

Fig. 3. Dry cooling tower in foreground, wet cooling tower in background in the THTR-300 pebble bed Th reactor, Germany.

Four approaches to a thorium reactor are under consideration:

1. Use of a liquid molten Th fluoride salt,

2. Use of a pebble bed graphite moderated and He gas cooled reactor,

3. The use of a seed and blanket solid fuel with a thermal Light Water Reactor (LWR) cycle,

4. A driven system using fusion or accelerator generated neutrons.

\section{Thorium abundance}

Thorium is four times as abundant than uranium in the Earth's crust and provides a fertile isotope for breeding of the fissile uranium isotope $U^{233}$ in a thermal or fast neutron spectrum.

In the Shippingport reactor it was used in the oxide form. In the HTGR it was used in metallic form embedded in graphite. The MSBR used graphite as a moderator and hence was a thermal breeder and a chemically stable fluoride salt, eliminating the need to process or to dispose of fabricated solid fuel elements. The fluid fuel allows the separation of the 
stable and radioactive fission products for disposal. It also offers the possibility of burning existing actinides elements and does need an enrichment process like the $\mathrm{U}^{235}-\mathrm{Pu}^{239}$ fuel cycle.

Thorium is abundant in the Earth's crust, estimated at 120 trillion tons. The Monazite black sand deposits are composed of 3-22 percent of thorium. It can be extracted from granite rocks and from phosphate rock deposits, rare earths, tin ores, coal and uranium mines tailings.

It has even been suggested that it can be extracted from the ash of coal power plants. A 1,000 MWe coal power plant generates about 13 tons of thorium per year in its ash. Each ton of thorium can in turn generate 1,000 MWe of power in a well optimized thorium reactor. Thus a coal power plant can conceptually fuel 13 thorium plants of its own power. From a different perspective, 1 pound of Th has the energy equivalent of 5,000 tons of coal. There are 31 pounds of Th in 5,000 tons of coal. If the Th were extracted from the coal, it would thus yield 31 times the energy equivalent of the coal.

The calcium sulfate or phospho-gypsum resulting as a waste from phosphorites or phosphate rocks processing into phosphate fertilizer contains substantial amounts of unextracted thorium and uranium.

Uranium mines with brannerite ores generated millions of tons of surface tailings containing thoria and rare earths.

The United States Geological Survey (USGS), as of 2010, estimated that the USA has reserves of 440,000 tons of thorium ore. A large part is located on properties held by Thorium Energy Inc. at Lemhi Pass in Montana and Idaho (Fig. 5). This compares to a previously estimated 160,000 tons for the entire USA.

The next highest global thorium ores estimates are for Australia at 300,000 tons and India with 290,000 tons.

\section{Thorium primary minerals}

Thorium occurs in several minerals:

1. Monazite, $(\mathrm{Ce}, \mathrm{La}, \mathrm{Y}, \mathrm{Th}) \mathrm{PO}_{4}$, a rare earth-thorium phosphate with 5-5.5 hardness. Its content in Th is 3-22 percent with 14 percent rare earth elements and yttrium. It occurs as a yellowish, reddish-brown to brown, with shades of green, nearly white, yellowish brown and yellow ore. This is the primary source of the world's thorium production. Until World War II, thorium was extracted from Monazite as a primary product for use in products such as camping lamp mantles. After World War II, Monazite has been primarily mined for its rare earth elements content. Thorium was extracted in small amounts and mainly discarded as waste.

2. Thorite, $(\mathrm{Th}, \mathrm{U}) \mathrm{SiO}_{4}$ is a thorium-uranium silicate with a 4.5 hardness with yellow, yellow-brown, red-brown, green, and orange to black colors. It shares a 22 percent Th and a 22 percent $U$ content. This ore has been used as a source of uranium, particularly the uranium rich uranothorite, and orangite; an orange colored calcium-rich thorite variety.

3. Brocktite, $(\mathrm{Ca}, \mathrm{Th}, \mathrm{Ce})\left(\mathrm{PO}_{4}\right) \mathrm{H}_{2} \mathrm{O}$.

4. Xenotime, $(\mathrm{Y}, \mathrm{Th}) \mathrm{PO}_{4}$.

5. Euxenite, $(\mathrm{Y}, \mathrm{Ca}, \mathrm{Ce}, \mathrm{U}, \mathrm{Th})(\mathrm{Nb}, \mathrm{Ta}, \mathrm{Ti})_{2} \mathrm{O}_{6}$.

6. Iron ore, $(\mathrm{Fe})$-rare earth elements-Th-apatite, Freta deposits at Pea Ridge, Missouri, Mineville, New York, and Scrub Oaks, New Jersey. 


$\begin{array}{ll}\begin{array}{l}\text { Ore } \\ \text { Thorite }\end{array} & \begin{array}{l}\text { Composition } \\ (\mathrm{Th}, \mathrm{U}) \mathrm{SiO}_{4}\end{array} \\ \text { Thorianite } & \left(\mathrm{ThO}{ }_{2}+\mathrm{UO}_{2}\right) \\ \text { Thorogummite } & \mathrm{Th}(\mathrm{SiO} 4)_{1-\mathrm{x}}(\mathrm{OH})_{4 \mathrm{x}} \\ \text { Monazite } & (\mathrm{Ce}, \mathrm{La}, \mathrm{Y}, \mathrm{Th}) \mathrm{PO}_{4} \\ \text { Brocktite } & (\mathrm{Ca}, \mathrm{Th}, \mathrm{Ce})\left(\mathrm{PO}_{4}\right) \mathrm{H}_{2} \mathrm{O} \\ \text { Xenotime } & (\mathrm{Y}, \mathrm{Th}) \mathrm{PO}_{4} \\ \text { Euxenite } & (\mathrm{Y}, \mathrm{Ca}, \mathrm{Ce}, \mathrm{U}, \mathrm{Th})(\mathrm{Nb}, \mathrm{Ta}, \mathrm{Ti})_{2} \mathrm{O}_{6} \\ \text { Iron ore } & \mathrm{Fe}+\text { rare earths }+\mathrm{Th} \text { apatite }\end{array}$

Table 2. Major Thorium ores compositions.

\section{Global and USA thorium resources}

Estimates of the available Th resources vary widely. The largest known resources of Th occur in the USA followed in order by Australia, India, Canada, South Africa, Brazil, and Malaysia.

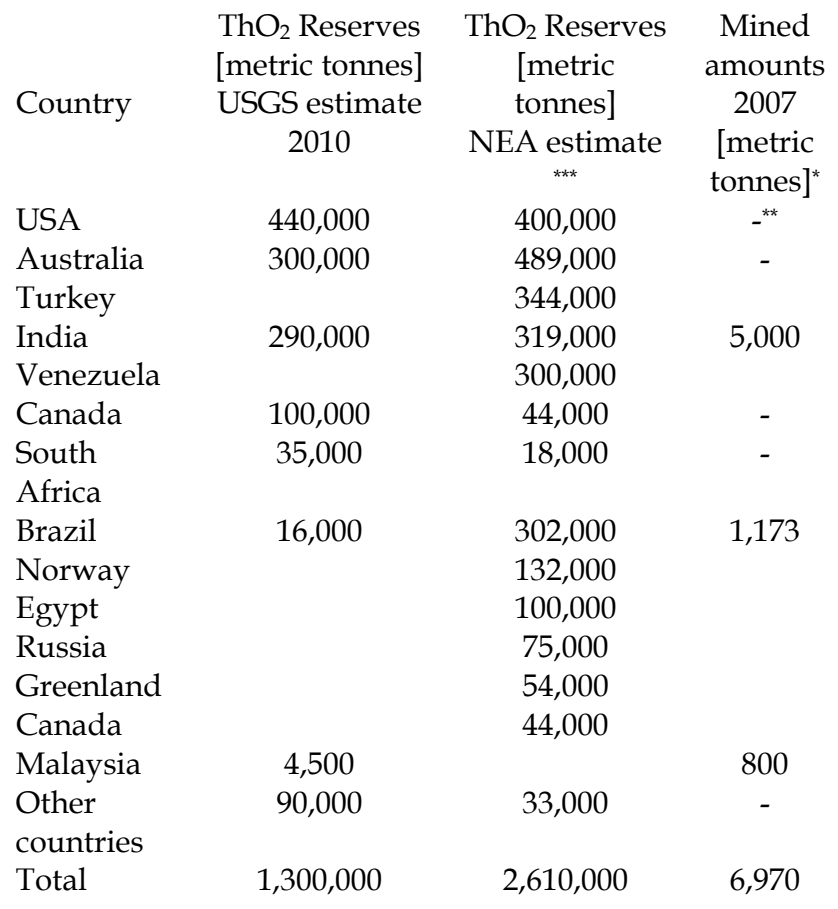

* Average Th content of 6-8 percent.

${ }^{* *}$ Last mined in 1994.

*** Reasonably assured and inferred resources available at up to $\$ 80 / \mathrm{kg}$ Th.

Table 3. Estimated Global Thorium Resources (Van Gosen et. al., 2009). 
The Steenkampskraal Mine in South Africa, located $350 \mathrm{~km}$ Northwest of Cape Town was operated by the Anglo American Company as the world's largest producer of Thorium and rare earth elements over the period 1952-1963. It was acquired by the Rare Earth Extraction Company (Rareco).

Concentrated deposits occur as vein deposits, and disseminated deposits occur as massive carbonatite stocks, alkaline intrusions, and black sand placer or alluvial stream and beach deposits.

Carbonatites are rare carbonate igneous rocks formed by magmatic or metasomatic processes. Most of these are composed of 50 percent or higher carbonate minerals such as calcite, dolomite and/or ankerite. They occur near alkaline igneous rocks.

The alkaline igneous rocks, also referred to as alkali rocks, have formed from magmas and fluids so enriched in alkali elements that $\mathrm{Na}$ and $\mathrm{K}$ bearing minerals form components of the rocks in larger proportion than usual igneous rocks. They are characterized by feldspathoid minerals and/or alkali pyroxenes and amphiboles (Hedrick, 2009).

Deposit type Mining District Location $\quad \mathrm{ThO}_{2}$ reserves

Vein deposits

Vein deposits

Massive Carbonatite stocks

Diamond Creek

Bear Lodge Mountains

Monroe Canyon

Mountain Pass district

Quartzite district

Cottonwood area

Gold Hill district

Capitan Mountain

Laughlin Peak

Wausau, Marathon

County

Bokan Mountain

Iron Hill

Mountain Pass

Stream deposits

Stream placers

Beach placers

Alkaline Intrusions

Total, USA

Hicks Dome

Montana-Idaho
Colorado
Idaho
Colorado

Idaho

Wyoming

Utah

California

Arizona

Arizona

New Mexico

New Mexico

New Mexico

Wisconsin

Alaska

Colorado

California

North, South

Carolina

Idaho

Florida-Georgia

Wyoming

Illinois [metric tonnes]

64,000

58,200

4,150

1,700 (thorium

veins)

690 (Carbonatite dikes)

Table 4. Locations of USA major $\mathrm{ThO}_{2}$ proven reserves (Hedrick, 2009). 


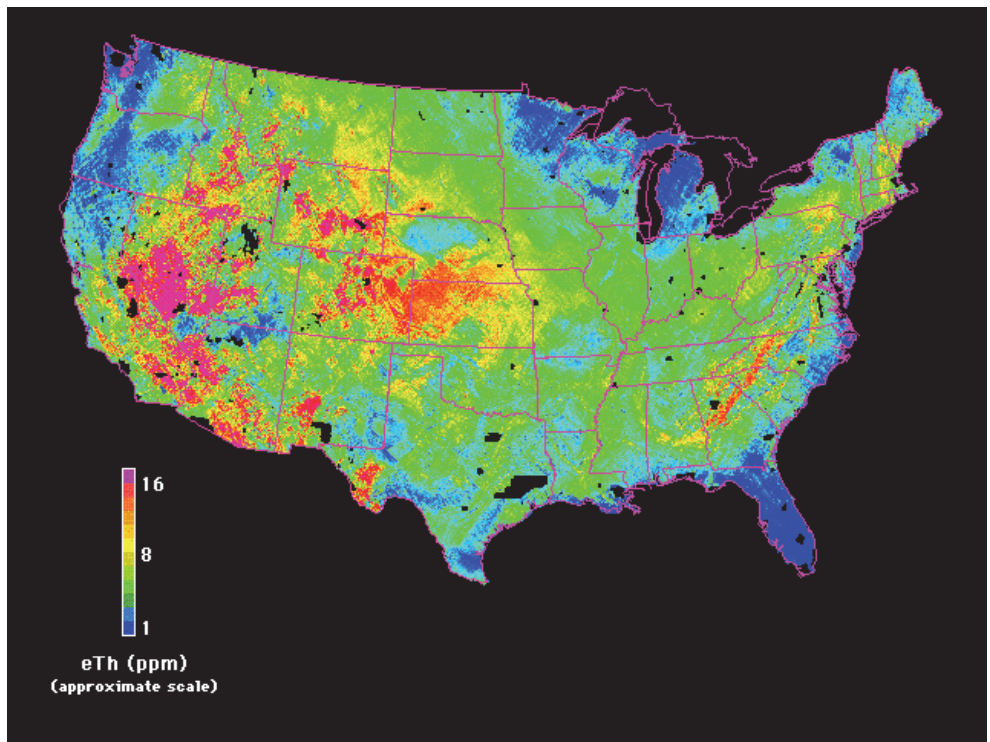

Fig. 4. Th concentrations in ppm and occurrences in the USA. Source: USA Geological Survey Digital Data Series DDS-9, 1993.

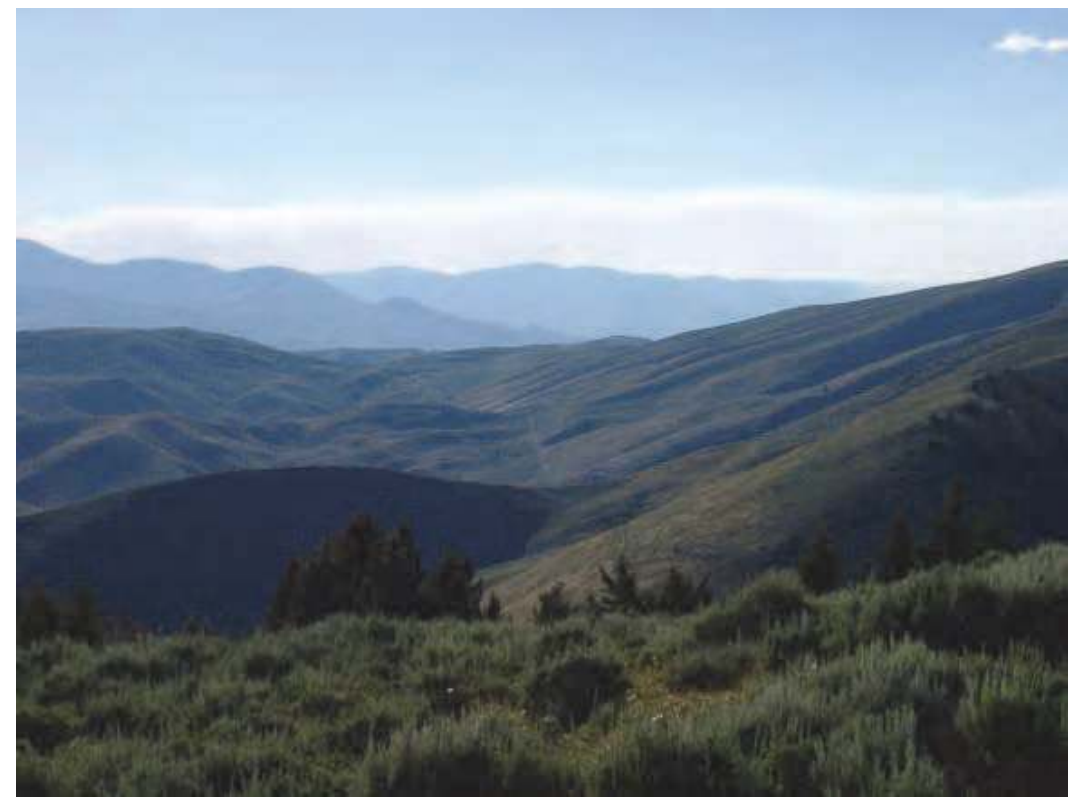

Fig. 5. Lehmi Pass is a part of Beaverhead Mountains along the continental divide on the Montana-Idaho border, USA. Its Th veins also contain rare earth elements, particularly Neodymium. 


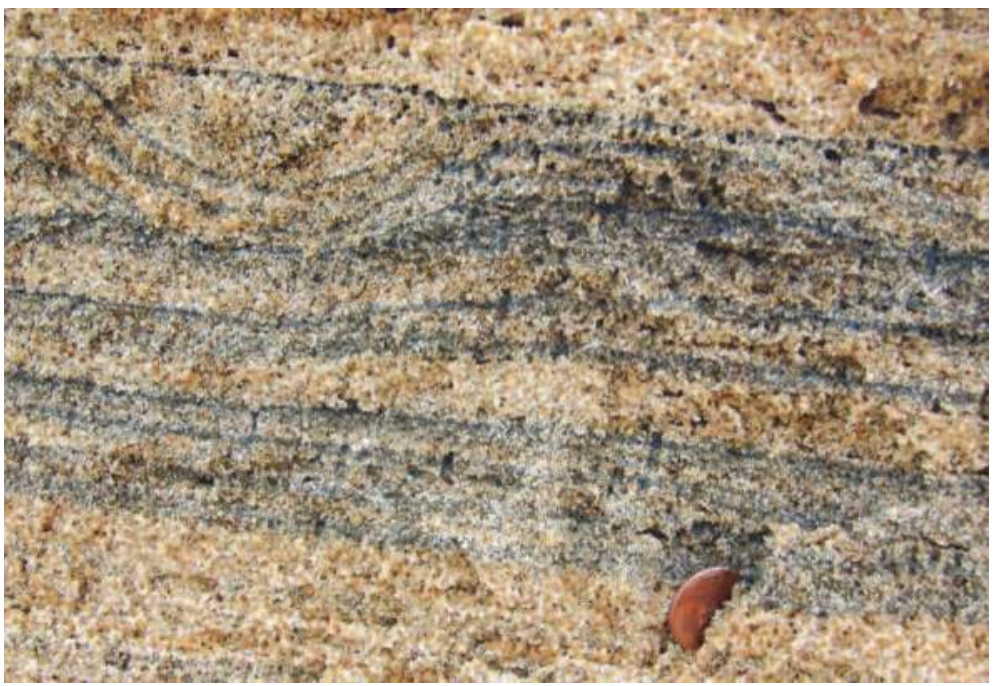

Fig. 6. Black sand Monazite layers in beach sand at Chennai, India. Photo: Mark A. Wilson (Hedrick, 2009).

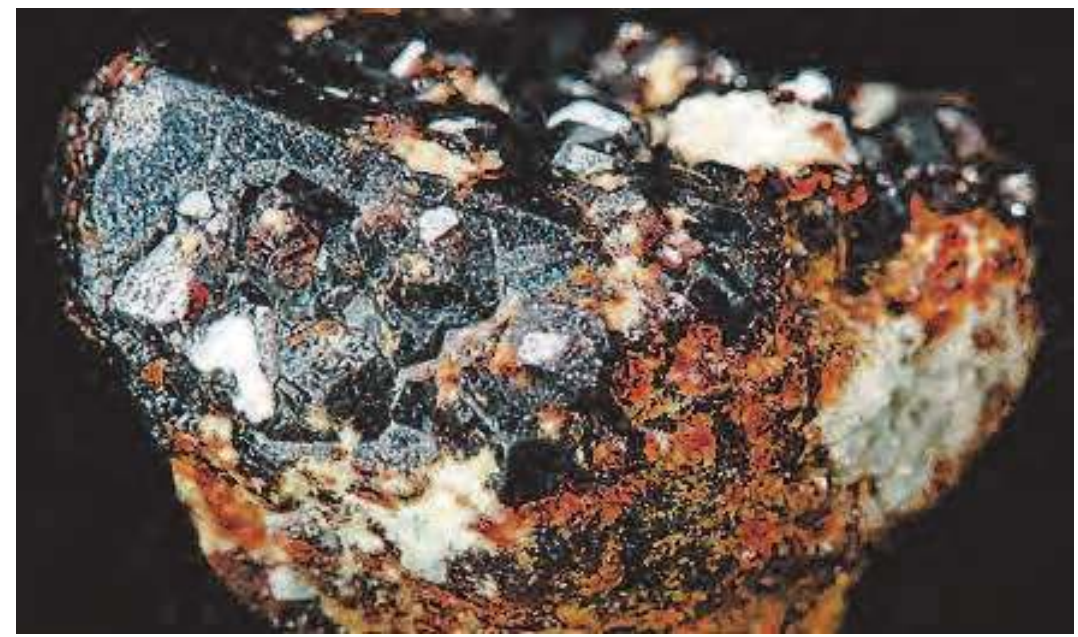

Fig. 7. Thorite (Th, $\mathrm{U}) \mathrm{SiO}_{4}$, a thorium-uranium silicate (Van Gosen, 2009).

\section{Global and USA uranium resources}

Depleting hydrocarbon fuel resources and the growing volatility in fossil fuel prices, have led to an expansion in nuclear power production. The Station Blackout accident, caused by a combined earthquake and tsunami event at the Fukushima Daiichi reactors on March 11, 2011 will lead to a reconsideration of the relative advantages and disadvantages of the existing $\mathrm{U}^{238}-\mathrm{Pu}^{239}$ fuel cycle against the alternative $\mathrm{Th}^{232-\mathrm{U}}{ }^{233}$ fuel cycle. 
As of 2010, there were 56 nuclear power reactors under construction worldwide, of which 21 are in China. Some are replacing older plants that are being decommissioned, and some are adding new installed capacity. The Chinese nuclear power program is probably the most ambitious in history. It aims at 50 new plants by the year 2025 with an additional 100, if not more, completed by the year 2050. Standardized designs, new technology, a disciplined effort to develop human skills and industrial capacities to produce nuclear power plant components all point to a likely decline in plant construction costs in coming years and growing interest in new nuclear projects with ensuing pressure on nuclear fuels.

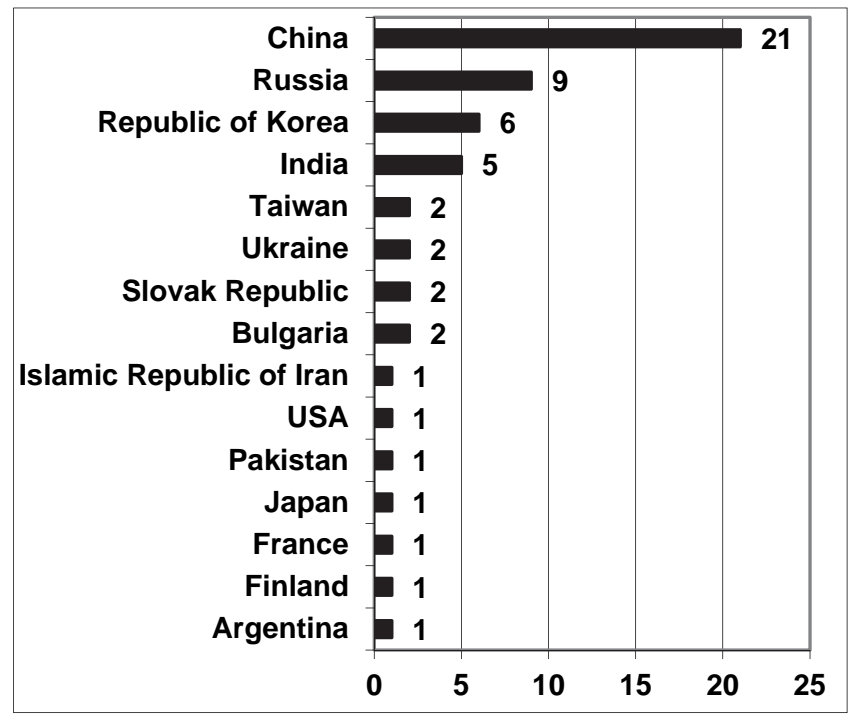

Fig. 8. Number of power reactors under construction worldwide. Total: 56 . Net electrical capacity: 51.9 MWe. Data source: IAEA, 2010.

It should be noted that there are currently 150 international reactor projects in some advanced permitting stage. An additional 300 projects are in some early planning stage. Added to a significant fraction of the currently 439 operating power reactors will likely double global nuclear capacity in the coming couple decades (most countries seem willing to try to extend the operating lives of existing reactors through safety-compliant upgrades and retrofits). Building a nuclear power plant practically requires contracting its fuel supply for 40-60 years. When adding all new projects it is reasonable to conclude that fuel requirements could double in the coming couple decades.

About 30 percent of the known recoverable global uranium oxide resources are found in Australia, followed by Kazakhstan (17 percent), Canada (12 percent), South Africa (8 percent), Namibia (6 percent), and Russia, Brazil and the USA, each with about 4 percent of the world production.

The uranium resources are classified into "conventional" and "non-conventional" resources. The conventional resources are further categorized into "Reasonably Assured Resources," RAR and the believed-to-exist "Inferred Resources," IR.

The RAR and IR categories are further subdivided according to the assumed exploitation cost in USA dollars. These cost categories are given as $<40 \$ / \mathrm{kg},<80 \$ / \mathrm{kg}$, and $<130 \$ / \mathrm{kg}$. 
The non-conventional resources are split into "Undiscovered Resources," UR, further separated into "Undiscovered Prognosticated Resources," UPR with assumed cost ranges of $<80$ \$/kg and < $130 \$ / \mathrm{kg}$, and "Undiscovered Speculative Resources" USR.

The USR numbers are given for an estimated exploitation cost of $<130 \$ / \mathrm{kg}$ and also for a category with an unknown cost.

In the twentieth century, the USA was the world leading uranium producer until it was surpassed by Canada and Australia. In 2007, Canada accounted for 23 percent and Australia for 21 percent of global production, with the USA at 4 percent. Africa is becoming a new frontier in uranium production with Namibia 7 percent, Niger 8 percent, and South Africa 1 percent. Exploration and new mine development is ongoing in Botswana, Tanzania. Jordan and Nigeria.

The federal, provincial and local governments in Australia have all unilaterally and forcefully banned the development of any new uranium mines, even though existing mines continue operation. The French company Areva was not successful in receiving approval to build a new uranium mine in Australia. It has mining activities in the Niger Republic and received exploration licenses in other countries such as Jordan.

Canadian producer Cameco rates as the first world producer of uranium oxide, followed by French Areva, and then Energy Resources of Australia (68 percent owned by Rio Tinto), which produces some 6,000 tons per year.

As of 2007, five operating uranium mines existed in the USA, with 3 in Texas, one in Wyoming and one in Northern Nebraska. The state of Texas has a positive attitude towards uranium mining, and energy production in general, with an advantageous regulatory framework that streamlines the permit process using in situ leaching of uranium. Texas, being an "Agreement State," implies that the USA Nuclear Regulatory Commission (NRC) has delegated its authority to the state regulatory agencies such as the Texas Commission on Environmental Quality (TCEQ), and companies deal directly with the state agencies in Texas rather than with the federal government's NRC. Most of the uranium mining operations in the USA and Kazakhstan use in situ leach methods, also designated as In Situ Recovery (ISR) methods. Conventional methods are used in 62 percent of U mining, with 28 percent as ISR and 9 percent as byproduct extraction.

By 2008, U production in the USA fell 15 percent to 1,780 tonnes $\mathrm{U}_{3} \mathrm{O}_{8}$. The $\mathrm{U}$ production in the USA is currently from one mill at White Mesa, Utah, and from 6 ISR operations. In 2007, four operating mines existed in the Colorado Plateau area: Topaz, Pandora, West Sunday and Sunday-St. Jude. Two old mines reopened in 2008: Rim Canyon and Beaver Shaft and the Van 4 mine came into production in 2009.

As of 2010, Cameco Resources operated two ISL operations: Smith Ranch-Highland Mine in Wyoming and Cross Butte Mine in Nebraska, with reserves of 15,000 tonnes $\mathrm{U}_{3} \mathrm{O}_{8}$. The Denison Mines Company produced 791,000 tonnes of $\mathrm{U}_{3} \mathrm{O}_{8}$ in 2008 at its $200 \mathrm{t} /$ day White Mesa mill in Southern Utah from its own and purchased ore, as well as toll milling.

Uranium in the Colorado Plateau in the USA has an average grade of 0.25 percent or 2,500 ppm uranium in addition to 1.7 percent vanadium within the Uravan Mineral Belt.

Goliad County, Texas has an average grade of 0.076 percent $(760 \mathrm{ppm})$ uranium oxide in sandstone deposits permeated by groundwater suggesting in situ leaching methods where water treated with carbon dioxide is injected into the deposit. The leachate is pumped and passed over ion exchange resins to extract the dissolved uranium. 


\begin{tabular}{|c|c|c|c|c|c|}
\hline Country & $\begin{array}{l}\text { Production } \\
\text { [tonnes U] }\end{array}$ & $\begin{array}{l}\text { Share of } \\
\text { world } \\
\text { production } \\
\text { [percent] }\end{array}$ & $\begin{array}{l}\text { Main } \\
\text { owner }\end{array}$ & $\begin{array}{l}\text { Extraction } \\
\text { method }\end{array}$ & Mine \\
\hline Canada & 6,383 & 15 & Cameco & Conv & $\begin{array}{l}\text { McArthur } \\
\text { River }\end{array}$ \\
\hline Australia & 4,527 & 10 & Rio Tinto & Conv & Ranger \\
\hline Namibia & 3,449 & 8 & Rio Tinto & Conv & Rסssing \\
\hline Australia & 3,344 & 8 & $\begin{array}{l}\text { BHP } \\
\text { Billiton }\end{array}$ & Byproduct & $\begin{array}{l}\text { Olympic } \\
\text { Dam }\end{array}$ \\
\hline Russia & 3,050 & 7 & ARMZ & Conv & $\begin{array}{l}\text { Priargunsk } \\
\mathrm{y}\end{array}$ \\
\hline Niger & 1,743 & 4 & Areva & Conv & Somair \\
\hline Canada & 1,368 & 3 & Cameco & Conv & $\begin{array}{l}\text { Rabbit } \\
\text { Lake }\end{array}$ \\
\hline Niger & 1,289 & 3 & Areva & Conv & Cominak \\
\hline Canada & 1,249 & 3 & Areva & Conv & McLean \\
\hline $\begin{array}{l}\text { Kazakhsta } \\
\mathrm{n}\end{array}$ & 1,034 & 2 & $\begin{array}{l}\text { Uranium } \\
\text { One }\end{array}$ & ISR & Akdata \\
\hline Total & 27,436 & 62 & & & \\
\hline
\end{tabular}

Table 5. World main producing uranium mines, 2008. Source: World Nuclear Association, WNA.

Phosphate rocks containing just $120 \mathrm{ppm}$ in $\mathrm{U}$ have been used as a source of uranium in the USA. The fertilizer industry produces large quantities of wet process phosphoric acid solution containing 0.1-0.2 gram/liter $(\mathrm{g} / \mathrm{l})$ of uranium, which represent a significant potential source of uranium.

\section{Nonproliferation characteristics}

In the Th-U233 fuel cycle, the hard gamma rays associated with the decay chain of the formed isotope $\mathrm{U}^{232}$ with a half life of 72 years and its spontaneous fission makes the $\mathrm{U}^{233}$ in the thorium cycle with high fuel burnup a higher radiation hazard from the perspective of proliferation than $\mathrm{Pu}^{239}$.

The $\mathrm{U}^{232}$ is formed from the fertile $\mathrm{Th}^{232}$ from two paths involving an $(\mathrm{n}, 2 \mathrm{n})$ reaction, which incidentally makes $\mathrm{Th}^{232}$ a good neutron multiplier in a fast neutron spectrum:

$$
\begin{aligned}
& { }_{0} n^{1}+{ }_{90} T h^{232} \rightarrow 2{ }_{0} n^{1}+{ }_{90} T h^{231} \\
& { }_{90} \mathrm{Th}^{231} \stackrel{25.52 h}{\longrightarrow}{ }_{-1} e^{0}+{ }_{91} \mathrm{~Pa}^{231} \\
& { }_{0} n^{1}+{ }_{91} \mathrm{~Pa}^{231} \rightarrow \gamma+{ }_{91} \mathrm{~Pa}^{232} \\
& { }_{91} \mathrm{~Pa}^{232} \stackrel{1.31 d}{\longrightarrow}{ }_{-1} e^{0}+{ }_{92} \mathrm{U}^{232}
\end{aligned}
$$


and another involving an $(\mathrm{n}, \mathrm{\gamma})$ radiative capture reaction:

$$
\begin{aligned}
& { }_{0} n^{1}+{ }_{90} T h^{232} \rightarrow \gamma+{ }_{90} T h^{233} \\
& { }_{90} T h^{233} \stackrel{22.2 m}{\longrightarrow}{ }_{-1} e^{0}+{ }_{91} P^{233} \\
& { }_{91} \mathrm{~Pa}^{233} \stackrel{27 d}{\longrightarrow}{ }_{-1} e^{0}+{ }_{92} U^{233} \\
& { }_{92} U^{233}+{ }_{0} n^{1} \rightarrow 2{ }_{0} n^{1}+{ }_{92} U^{232}
\end{aligned}
$$

The isotope $\mathrm{U}^{232}$ is also formed from a reversible $(n, 2 n)$ and $(n, \gamma)$ path acting on the bred U233:

$$
\begin{aligned}
& { }_{0} n^{1}+{ }_{92} U^{233} \rightarrow 2{ }_{0} n^{1}+{ }_{92} U^{232} \\
& { }_{0} n^{1}+{ }_{92} U^{232} \rightarrow \gamma+{ }_{92} U^{233}
\end{aligned}
$$

The isotope $\mathrm{Th}^{230}$ occurs in trace quantities in thorium ores that are mixtures of uranium and thorium. $U^{234}$ is a decay product of $U^{238}$ and it decays into $T^{230}$ that becomes mixed with the naturally abundant $\mathrm{Th}^{232}$. It occurs in secular equilibrium in the decay chain of natural uranium at a concentration of $17 \mathrm{ppm}$. The isotope $\mathrm{U}^{232}$ can thus also be produced from two successive neutron captures in $\mathrm{Th}^{230}$ :

$$
\begin{aligned}
& { }_{0} n^{1}+{ }_{90} T h^{230} \rightarrow \gamma+{ }_{90} T h^{231} \\
& { }_{90} T h^{231} \stackrel{25.52 h}{\longrightarrow}{ }_{-1} e^{0}+{ }_{91} P a^{231} \\
& { }_{0} n^{1}+{ }_{91} \mathrm{~Pa}^{231} \rightarrow \gamma+{ }_{91} \mathrm{~Pa}^{232} \\
& { }_{91} \mathrm{~Pa}^{232} \stackrel{1.31 d}{\longrightarrow}{ }_{-1} e^{0}+{ }_{92} U^{232}
\end{aligned}
$$

The hard 2.6 MeV gamma rays originate from $\mathrm{Tl}^{208}$ isotope in the decay chain of aged $\mathrm{U}^{232}$ which eventually decays into the stable $\mathrm{Pb}^{208}$ isotope:

$$
\begin{aligned}
& { }_{92} U^{232} \stackrel{72 a}{\longrightarrow}{ }_{90} \mathrm{Th}^{228}+{ }_{2} \mathrm{He}^{4} \\
& { }_{90} \mathrm{Th}^{228} \stackrel{1.913 a}{\longrightarrow}{ }_{88} \mathrm{Ra}^{224}+{ }_{2} \mathrm{He}^{4} \\
& { }_{88} \mathrm{Ra}^{224} \stackrel{3.66 d}{\longrightarrow}{ }_{86} \mathrm{Rn} n^{220}+{ }_{2} \mathrm{He}^{4} \\
& { }_{86} \mathrm{Rn}^{220} \stackrel{55.6 \mathrm{~s}}{\longrightarrow}{ }_{82} \mathrm{Po}^{216}+{ }_{2} \mathrm{He}^{4} \\
& { }_{84} \mathrm{Po}^{216} \stackrel{0.15 s}{\longrightarrow}{ }_{82} \mathrm{~Pb}^{212}+{ }_{2} \mathrm{He}^{4} \\
& { }_{82} \mathrm{~Pb}^{212} \stackrel{10.64 h}{\longrightarrow}{ }_{83} \mathrm{Bi}^{212}+{ }_{-1} e^{0} \\
& { }_{83} \mathrm{Bi}^{212} \stackrel{60.6 \mathrm{~m}}{\underset{64 \%}{\longrightarrow}}{ }_{84} \mathrm{Po}^{212}+{ }_{-1} e^{0} \\
& { }_{83} \mathrm{Bi}^{212} \stackrel{60.6 m}{36 \%}{ }_{81} \mathrm{Tl}^{208}+{ }_{2} \mathrm{He}^{4} \\
& { }_{84} \mathrm{Po}^{212} \stackrel{0.298 \mu \mathrm{s}}{\longrightarrow}{ }_{82} \mathrm{~Pb}^{208}(\text { stable })+{ }_{2} \mathrm{He}^{4} \\
& { }_{81} \mathrm{Tl}^{208} \stackrel{3.053 \mathrm{~m}}{\longrightarrow}{ }_{82} \mathrm{~Pb}^{208}(\text { stable })+{ }_{-1} e^{0}+\gamma(2.6146 \mathrm{MeV})
\end{aligned}
$$

As comparison, the $\mathrm{U}^{233}$ decay chain eventually decays into the stable $\mathrm{Bi}^{209}$ isotope: 


$$
\begin{aligned}
& { }_{92} U^{233} \stackrel{1.592 \times 10^{5} a}{\longrightarrow}{ }_{90} T^{229}+{ }_{2} \mathrm{He}^{4} \\
& { }_{90} \mathrm{Th}^{229} \stackrel{7340 a}{\longrightarrow}{ }_{88} \mathrm{Ra}^{225}+{ }_{2} \mathrm{He}^{4} \\
& { }_{88} R a^{225} \stackrel{14.8 d}{\longrightarrow}{ }_{89} A c^{225}+{ }_{-1} e^{0} \\
& { }_{89} A c^{225} \stackrel{10.0 d}{\longrightarrow}{ }_{87} \mathrm{Fr}^{221}+{ }_{2} \mathrm{He}^{4} \\
& { }_{87} \mathrm{Fr}^{221} \stackrel{4.8 m}{\longrightarrow}{ }_{85} \mathrm{At}^{217}+{ }_{2} \mathrm{He}^{4} \\
& { }_{85} A t^{217} \stackrel{32.3 m s}{\longrightarrow}{ }_{83} \mathrm{Bi}^{213}+{ }_{2} \mathrm{He}^{4} \\
& { }_{83} \mathrm{Bi}^{213} \stackrel{45.6 m}{\longrightarrow}{ }_{84} \mathrm{Po}^{213}+{ }_{-1} e^{0} \\
& { }_{84} \mathrm{Po}^{213} \stackrel{4.2 \mu \mathrm{s}}{\longrightarrow}{ }_{82} \mathrm{~Pb}^{209}+{ }_{2} \mathrm{He}^{4} \\
& { }_{82} \mathrm{~Pb}^{209} \stackrel{3.28 h}{\longrightarrow}{ }_{83} \mathrm{Bi}^{209}(\text { stable })+{ }_{-1} e^{0}
\end{aligned}
$$

A 5-10 proportion of $U^{232}$ in the $U^{232} U^{233}$ mixture has a radiation equivalent dose rate of about $1,000 \mathrm{cSv}$ (rem)/hr at a 1 meter distance for decades making it a highly proliferation resistant cycle if the $\mathrm{Pa}^{233}$ is not separately extracted and allowed to decay into pure $\mathrm{U}^{233}$.

The $\mathrm{Pa}^{233}$ cannot be chemically separated from the $\mathrm{U}^{232}$ if the design forces the fuel to be exposed to the neutron flux without a separate blanket region, making the design fail-safe with respect to proliferation and if a breeding ratio of unity is incorporated in the design.

Such high radiation exposures would lead to incapacitation within 1-2 hours and death within 1-2 days of any potential proliferators.

The International Atomic Energy Agency (IAEA) criterion for fuel self protection is a lower dose equivalent rate of $100 \mathrm{cSv}(\mathrm{rem}) / \mathrm{hr}$ at a 1 meter distance. Its denaturing requirement for $\mathrm{U}^{235}$ is 20 percent, for $\mathrm{U}^{233}$ with $\mathrm{U}^{238}$ it is 12 percent, and for $\mathrm{U}^{233}$ denaturing with $\mathrm{U}^{232}$ it is 1 percent.

The Indian Department of Atomic Energy (DAE) had plans on cleaning U233 down to a few ppm of $\mathrm{U}^{232}$ using Laser Isotopic Separation (LIS) to reduce the dose to the occupational workers.

The contamination of $U^{233}$ by the $U^{232}$ isotope is mirrored by another introduced problem from the generation of $U^{232}$ in the recycling of $T^{232}$ due to the presence of the highly radioactive $\mathrm{Th}^{228}$ from the decay chain of $\mathrm{U}^{232}$.

\section{Radiation dosimetry}

The International Atomic Energy Agency (IAEA) criterion for occupational protection is an effective dose of $100 \mathrm{cSv}$ (rem)/ hr at a 1 meter distance from the radiation source.

It is the decay product $\mathrm{Tl}^{208}$ in the decay chain of $\mathrm{U}^{232}$ and not $\mathrm{U}^{232}$ itself that generates the hard gamma rays. The $\mathrm{T}^{208}$ would appear in aged $\mathrm{U}^{233}$ over time after separation, emitting a hard $2.6416 \mathrm{MeV}$ gamma ray photon. It accounts for 85 percent of the total effective dose 2 years after separation. This implies that manufacturing of U233 should be undertaken in freshly purified $U^{233}$. Aged $U^{233}$ would require heavy shielding against gamma radiation.

In comparison, in the U-Pu' ${ }^{239}$ fuel cycle, $\mathrm{Pu}^{239}$ containing $\mathrm{Pu}^{241}$ with a half life of 14.4 years, the most important source of gamma ray radiation is from the $\mathrm{Am}^{241}$ isotope with a 433 years half life that emits low energy gamma rays of less than $0.1 \mathrm{MeV}$ in energy. For weapons grade $\mathrm{Pu}^{239}$ with about 0.36 percent $\mathrm{Pu}^{241}$ this does not present a major hazard but the radiological hazard becomes significant for reactor grade $\mathrm{Pu}^{239}$ containing about 9-10 percent $\mathrm{Pu}^{241}$. 
The generation of $\mathrm{Pu}^{241}$ as well as $\mathrm{Pu}^{240}$ and $\mathrm{Am}^{241}$ from $\mathrm{U}^{238}$ follows the following path:

$$
\begin{aligned}
& { }_{0} n^{1}+{ }_{92} U^{238} \rightarrow \gamma+{ }_{92} U^{239} \\
& { }_{92} U^{239} \stackrel{23.5 m}{\longrightarrow}{ }_{-1} e^{0}+{ }_{93} N p^{239} \\
& { }_{93} N p^{239} \stackrel{2.35 d}{\longrightarrow}{ }_{-1} e^{0}+{ }_{94} P u^{239} \\
& { }_{0} n^{1}+{ }_{94} P u^{239} \rightarrow \gamma+{ }_{94} P u^{240} \\
& { }_{0} n^{1}+{ }_{94} P u^{240} \rightarrow \gamma+{ }_{94} P u^{241} \\
& { }_{94} P u^{241} \stackrel{14.7 a}{\longrightarrow}{ }_{-1} e^{0}+{ }_{95} A m^{241}
\end{aligned}
$$

Plutonium containing less than 6 percent $\mathrm{Pu}^{240}$ is considered as weapons-grade.

The gamma rays from $\mathrm{Am}^{241}$ are easily shielded against with $\mathrm{Pb}$ shielding. Shielding against the neutrons from the spontaneous fissions in the even numbered $\mathrm{Pu}^{238}$ and $\mathrm{Pu}^{240}$ isotopes accumulated in reactor grade plutonium requires the additional use of a thick layer of a neutron moderator containing hydrogen such as paraffin or plastic, followed by a layer of neutron absorbing material and then additional shielding against the gamma rays generated from the neutron captures.

The generation of $\mathrm{Pu}^{238}$ and $\mathrm{Np}^{237}$ by way of $(\mathrm{n}, 2 \mathrm{n})$ rather than $(\mathrm{n}, \mathrm{\gamma})$ reactions, follows the path:

\begin{tabular}{|c|c|c|c|c|}
\hline $\begin{array}{c}\text { Isotopic } \\
\text { composition } \\
\text { [percent] }\end{array}$ & $\begin{array}{c}\mathrm{Pu}^{239} \\
\text { weapons } \\
\text { grade }\end{array}$ & $\begin{array}{l}\mathrm{Pu}^{239} \\
\text { reactors } \\
\text { grade }\end{array}$ & U233 & $\begin{array}{c}\mathrm{U}^{233}+1 \\
\text { ppm U232 }\end{array}$ \\
\hline $\mathrm{U} 232$ & & & 0.0000 & 0.0001 \\
\hline U233 & & & 100.0000 & 99.9999 \\
\hline $\mathrm{Pu}^{238}$ & 0.0100 & 1.3000 & & \\
\hline $\mathrm{Pu}^{239}$ & 93.8000 & 60.3000 & & \\
\hline $\mathrm{Pu}^{240}$ & 5.8000 & 24.3000 & & \\
\hline $\mathrm{Pu}^{241}$ & 0.3500 & 9.1000 & & \\
\hline $\mathrm{Pu}^{242}$ & 0.0200 & 5.0000 & & \\
\hline $\begin{array}{l}\text { Density } \\
{\left[\mathrm{gm} / \mathrm{cm}^{3}\right]}\end{array}$ & 19.86 & 19.86 & 19.05 & 19.05 \\
\hline Radius [cm] & 3.92 & 3.92 & 3.96 & 3.96 \\
\hline Weight $[\mathrm{kg}]$ & 5 & 5 & 5 & 5 \\
\hline
\end{tabular}

$$
\begin{aligned}
& { }_{0} n^{1}+{ }_{92} U^{238} \rightarrow 2{ }_{0} n^{1}+{ }_{92} U^{237} \\
& { }_{92} U^{237} \stackrel{6.75 d}{\longrightarrow}{ }_{-1} e^{0}+{ }_{93} N p^{237} \\
& { }_{0} n^{1}+{ }_{93} N p^{237} \rightarrow \gamma+{ }_{93} N p^{238} \\
& { }_{93} N p^{238} \stackrel{2.12 d}{\longrightarrow}{ }_{-1} e^{0}+{ }_{94} P u^{238}
\end{aligned}
$$

The production of $\mathrm{Pu}^{238}$ for radioisotopic heat and electric sources for space applications follows the path of chemically separating $\mathrm{Np}^{237}$ from spent LightWater Reactors (LWRs) fuel and then neutron irradiating it to produce $\mathrm{Pu}^{238}$.

Table 6. Typical compositions of fuels in the uranium and thorium fuel cycles (Kang, von Hippel, 2001). 


\begin{tabular}{|c|c|c|}
\hline $\begin{array}{c}\text { Fuel, } \\
\text { U232/U233 }\end{array}$ & $\begin{array}{c}\text { Time to } 5 \mathrm{cSv} \\
\text { effective dose } \\
{[\mathrm{hr}]}\end{array}$ & $\begin{array}{c}\text { Effective dose } \\
\text { rate } \\
\mathrm{cSv} / \mathrm{hr}\end{array}$ \\
\hline 0.01 & 0.039 & 127.0000 \\
\hline 100 ppm & 3.937 & 1.2700 \\
\hline 5 ppm & 84.746 & 0.0590 \\
\hline $1 \mathrm{ppm}$ & 384.615 & 0.0130 \\
\hline Reactor grade $\mathrm{Pu}^{239}$ & 609.756 & 0.0082 \\
\hline Weapons grade $\mathrm{Pu}^{239}$ & 3846.154 & 0.0013 \\
\hline
\end{tabular}

Table 7. Glove box operation dose rate required to accumulate a limiting occupational $5 \mathrm{cSv}$ (rem) dose equivalent from a $5 \mathrm{~kg}$ metal sphere, one year after separation at a $1 / 2$ meter distance(Kang, von Hippel, 2001).

Both reactor-grade plutonium and $U^{233}$ with $U^{232}$ would pose a significant radiation dose equivalent hazard for manufacturing personnel as well as military personnel, which precludes their use in weapons manufacture in favor of enriched $U^{235}$ and weapons-grade $\mathrm{Pu}^{239}$.

\begin{tabular}{|c|c|c|c|c|c|c|}
\hline \multirow[t]{2}{*}{ Material } & \multirow[t]{2}{*}{$\begin{array}{l}\text { Type of } \\
\text { radiation }\end{array}$} & \multicolumn{5}{|c|}{$\begin{array}{l}\text { Dose equivalent rate at time after separation } \\
\qquad[\mathrm{cSv}(\mathrm{rem}) / \mathrm{hr}]\end{array}$} \\
\hline & & $0 \mathrm{yr}$ & $1 \mathrm{yr}$ & $5 \mathrm{yr}$ & $10 \mathrm{yr}$ & $15 \mathrm{yr}$ \\
\hline Pure U233 & $\gamma$ total & 0.32 & 0.42 & 0.84 & 1.35 & 1.89 \\
\hline \multirow[t]{2}{*}{$\mathrm{U}^{233}+1$ ppm U232 } & $\gamma$ total & 0.32 & 13.08 & 35.10 & 39.57 & 39.17 \\
\hline & $\gamma$ from Tl208 & 0.00 & 11.12 & 29.96 & 33.48 & 32.64 \\
\hline $\mathrm{Pu}^{239}$ & $\gamma$ & 0.49 & 0.71 & 1.16 & 1.57 & 1.84 \\
\hline \multirow[t]{2}{*}{ weapons grade } & neutrons & 0.56 & 0.56 & 0.56 & 0.56 & 0.56 \\
\hline & $\gamma+$ neutron & 1.05 & 1.27 & 1.72 & 2.13 & 2.40 \\
\hline $\mathrm{Pu}^{239}$ & $\gamma$ total & 0.49 & 5.54 & 16.72 & 28.64 & 37.54 \\
\hline \multirow[t]{3}{*}{ Reactor grade } & $\begin{array}{l}y \text { from } \\
\text { Am }^{241}\end{array}$ & 0.00 & 3.24 & 14.60 & 26.00 & 34.80 \\
\hline & neutrons & 2.66 & 2.66 & 2.65 & 2.64 & 2.63 \\
\hline & $\gamma+$ neutrons & 3.15 & 8.20 & 19.37 & 31.28 & 40.17 \\
\hline
\end{tabular}

Table 8. Dose equivalent rates in cSv (rem)/ hr from $5 \mathrm{~kg}$ metal spheres at a $1 / 2$ meter distance for different times after separation (Kang, von Hippel, 2001).

\section{Actinides production, waste disposal Issues}

There has been a new interest in the Th cycle in Europe and the USA since it can be used to increase the achievable fuel burnup in LWRs in a once through fuel cycle while significantly reducing the transuranic elements in the spent fuel. A nonproliferation as well as transuranics waste disposal consideration is that just a single neutron capture reaction in $\mathrm{U}^{238}$ is needed to produce $\mathrm{Pu}^{239}$ from $\mathrm{U}^{238}$ :

$$
\begin{aligned}
{ }_{0} \mathrm{n}^{1}+{ }_{92} \mathrm{U}^{238} \rightarrow{ }_{92} \mathrm{U}^{239}+\gamma \\
{ }_{92} \mathrm{U}^{239} \stackrel{23.5 m}{\longrightarrow}{ }_{93} \mathrm{~Np}^{239}+{ }_{-1} \mathrm{e}^{0} \\
{ }_{93} \mathrm{~Np}^{239} \stackrel{2.35 d}{\longrightarrow}{ }_{94} \mathrm{Pu}^{239}+{ }_{-1} \mathrm{e}^{0}
\end{aligned}
$$


whereas a more difficult process of fully 5 successive neutron captures are needed to produce the transuranic $\mathrm{Np}^{237}$ from $\mathrm{Th}^{232}$ :

$$
\begin{aligned}
& { }_{0} \mathrm{n}^{1}+{ }_{90} \mathrm{Th}^{232} \rightarrow{ }_{90} \mathrm{Th}^{233}+\gamma \\
& { }_{0} \mathrm{n}^{1}+{ }_{90} \mathrm{Th}^{233} \rightarrow{ }_{90} \mathrm{Th}^{234}+\gamma \\
& { }_{90} \mathrm{Th}^{234} \stackrel{24.1 d}{\longrightarrow}{ }_{91} \mathrm{~Pa}^{234}+{ }_{-1} \mathrm{e}^{0} \\
& { }_{91} \mathrm{~Pa}^{234} \stackrel{6.70 h}{\longrightarrow}{ }_{92} \mathrm{U}^{234}+{ }_{-1} \mathrm{e}^{0} \\
& { }_{0} \mathrm{n}^{1}+{ }_{92} \mathrm{U}^{234} \rightarrow{ }_{92} \mathrm{U}^{235}+\gamma \\
& { }_{0} \mathrm{n}^{1}+{ }_{92} \mathrm{U}^{235} \rightarrow{ }_{92} \mathrm{U}^{236}+\gamma \\
& { }_{0} \mathrm{n}^{1}+{ }_{92} \mathrm{U}^{236} \rightarrow{ }_{92} \mathrm{U}^{237}+\gamma \\
& { }_{92} \mathrm{U}^{237} \stackrel{6.75 d}{\longrightarrow}{ }_{93} \mathrm{~Np}^{237}+{ }_{-1} \mathrm{e}^{0}
\end{aligned}
$$

This implies a low yield of $\mathrm{Np}^{237}$ however, as an odd numbered mass number isotope posing a possible proliferation concern; whatever small quantities of it are produced, provisions must be provided in the design to have it promptly recycled back for burning in the fast neutron spectrum of the fusion part of the hybrid.

In fact, it is more prominently produced in thermal fission light water reactors using the uranium cycle and would be produced; and burned, in fast fission reactors through the (n, $2 n)$ reaction channel with $\mathrm{U}^{238}$ according to the much simpler path:

$$
\begin{aligned}
& { }_{0} n^{1}+{ }_{92} U^{238} \rightarrow 2{ }_{0} n^{1}+{ }_{92} U^{237} \\
& { }_{92} U^{237} \stackrel{6.75 d}{\longrightarrow}{ }_{93} N p^{237}+{ }_{-1} e^{0}
\end{aligned}
$$

The $\mathrm{Np}^{237}$ gets transmuted in the Th ${ }^{232}$ fuel cycle into $\mathrm{Pu}^{238}$ with a short half-life of 87.74 years:

$$
\begin{aligned}
& { }_{0} n^{1}+{ }_{93} N p^{237} \rightarrow{ }_{93} N p^{238}+\gamma \\
& { }_{93} N p^{238} \stackrel{2.12 d}{\longrightarrow}{ }_{94} P u^{238}+{ }_{-1} e^{0}
\end{aligned}
$$

A typical 1,000 MWe Light Water Reactor (LWR) operating at an 80 percent capacity factor produces about $13 \mathrm{kgs}$ of $\mathrm{Np}^{237}$ per year.

This has led to suggested designs where Th232 replaces $U^{238}$ in LWRs fuel and accelerator driven fast neutron subcritical reactors that would breed $U^{233}$ from $T^{232}$.

Incidentally, whereas the $\mathrm{Pu}^{238}$ isotope is produced in the Th fuel cycle, it is the $\mathrm{Pu}^{240}$ isotope with a longer 6,537 years half-life, that is produced in the U-Pu fuel cycle:

$$
\begin{aligned}
{ }_{0} \mathrm{n}^{1}+{ }_{92} \mathrm{U}^{238} & \rightarrow{ }_{92} \mathrm{U}^{239}+\gamma \\
{ }_{92} \mathrm{U}^{239} & \rightarrow{ }_{93} \mathrm{~Np}^{239}+{ }_{-1} \mathrm{e}^{0}+v^{*}+\gamma \\
{ }_{93} \mathrm{~Np}^{239} & \rightarrow{ }_{94} \mathrm{Pu}^{239}+{ }_{-1} \mathrm{e}^{0}+v^{*}+\gamma \\
{ }_{0} \mathrm{n}^{1}+{ }_{94} \mathrm{Pu}^{239} & \rightarrow{ }_{94} \mathrm{Pu}^{240}+\gamma
\end{aligned}
$$




\section{Thorium fission-hybrid fuel cycle}

The thorium fusion fission hybrid is discussed as a sustainable longer term larger resource base to the fast breeder fission reactor concept. In addition, it offers a manageable waste disposal process, burning of the produced actinides and serious nonproliferation characteristics.

With the present day availability of fissile $\mathrm{U}^{235}$ and $\mathrm{Pu}^{239}$, and available fusion and accelerator neutron sources, a new look at the thorium-U233 fuel cycle is warranted. Since no more than 7 percent of the $\mathrm{ThO}_{2}$ as a breeding seed fuel can be added to a Heavy Water Reactor, HWR before criticality would not be achievable; this suggests that fusion and accelerator sources are the appropriate alternative for the implementation of the Thorium fuel cycle.

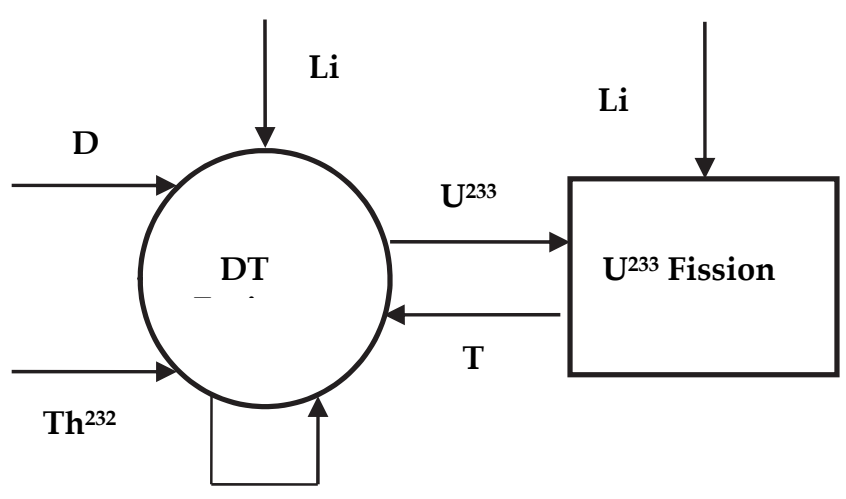

T

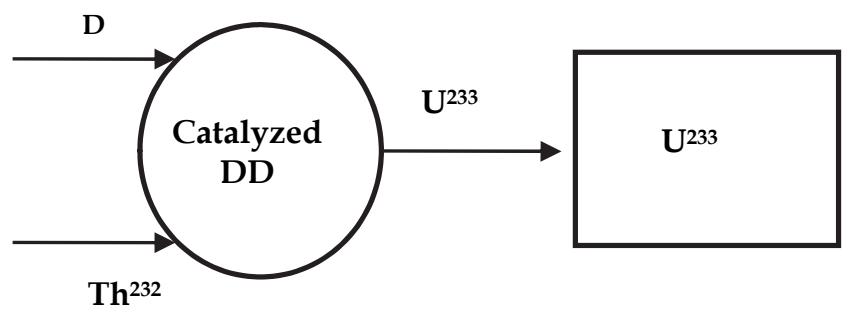

Fig. 9. Material flows in the DT (top) and Catalyzed DD fusion-fission hybrid (bottom) alternatives with $\mathrm{U}^{233}$ breeding from Th232. The Catalyzed DD approach does not contain the $\mathrm{Li}$ and $\mathrm{T}$ paths (Ragheb, 1981).

The use of the thorium cycle in a fusion fission hybrid could bypass the stage of fourth generation breeder reactors in that the energy multiplication in the fission part allows the satisfaction of energy breakeven and the Lawson condition in magnetic and inertial fusion reactor designs. This allows for the incremental development of the technology for the eventual introduction of a pure fusion technology.

For an immediate application of the fusion hybrid using the Th cycle, the DT fusion fuel cycle can be used: 


$$
{ }_{1} \mathrm{D}^{2}+{ }_{1} \mathrm{~T}^{3} \rightarrow{ }_{2} \mathrm{He}^{4}(3.52 \mathrm{MeV})+{ }_{0} \mathrm{n}^{1}(14.06 \mathrm{MeV})+17.58 \mathrm{MeV}
$$

The tritium would have to be bred from the abundant supplies of lithium using the reactions with its two isotopes:

$$
\begin{aligned}
& { }_{3} \mathrm{Li}^{6}+{ }_{0} \mathrm{n}^{1} \text { (thermal) } \rightarrow{ }_{2} \mathrm{He}^{4}(2.05 \mathrm{MeV})+{ }_{1} \mathrm{~T}^{3}(2.73 \mathrm{MeV})+4.78 \mathrm{MeV} \\
& { }_{3} \mathrm{Li}^{7}+{ }_{0} \mathrm{n}^{1} \text { (fast) } \rightarrow{ }_{2} \mathrm{He}^{4}+{ }_{0} \mathrm{n}^{1}+{ }_{1} \mathrm{~T}^{3}-2.47 \mathrm{MeV}
\end{aligned}
$$

In this case a molten salt containing $\mathrm{Li}$ for tritium breeding as well as Th for $\mathrm{U}^{233}$ breeding can be envisioned:

$$
\mathrm{LiF} . \mathrm{BeF}_{2} \cdot \mathrm{ThF}_{4}
$$

For a practically unlimited supply of deuterium from water at a deuterium to hydrogen ratio of $\mathrm{D} / \mathrm{H}=150 \mathrm{ppm}$ in the world oceans, one can envision the use of the catalyzed DD reaction in the fusion island:

$$
\begin{aligned}
& { }_{1} D^{2}+{ }_{1} D^{2} \rightarrow{ }_{1} T^{3}(1.01)+{ }_{1} H^{1}(3.03)+4.04 \mathrm{MeV} \\
& { }_{1} D^{2}+{ }_{1} D^{2} \rightarrow{ }_{2} \mathrm{He}^{3}(0.82)+{ }_{0} n^{1}(2.45)+3.27 \mathrm{MeV} \\
& { }_{1} D^{2}+{ }_{1} T^{3} \rightarrow{ }_{2} \mathrm{He}^{4}(3.52)+{ }_{0} n^{1}(14.06)+17.58 \mathrm{MeV} \\
& { }_{1} D^{2}+{ }_{2} \mathrm{He}^{3} \rightarrow{ }_{2} \mathrm{He}^{4}(3.67)+{ }_{1} \mathrm{H}^{1}(14.67)+18.34 \mathrm{MeV} \\
& \hline 6_{1} D^{2} \rightarrow 2 \mathrm{H}^{1}+2{ }_{2} \mathrm{He}^{4}+2{ }_{0} n^{1}+43.23 \mathrm{MeV}
\end{aligned}
$$

with each of the six deuterons contributing an energy release of $43.23 / 6=7.205 \mathrm{MeV}$.

For plasma kinetic reactions temperatures below $50 \mathrm{keV}$, the $\mathrm{DHe}^{3}$ reaction is not significant and the energy release would be $43.23-18.34=24.89$ with each of the five deuterons contributing an energy release of $24.89 / 5=4.978 \mathrm{MeV}$.

$$
\begin{aligned}
& { }_{1} D^{2}+{ }_{1} D^{2} \rightarrow{ }_{1} T^{3}(1.01)+{ }_{1} H^{1}(3.03)+4.04 \mathrm{MeV} \\
& { }_{1} D^{2}+{ }_{1} D^{2} \rightarrow{ }_{2} \mathrm{He}^{3}(0.82)+{ }_{0} n^{1}(2.45)+3.27 \mathrm{MeV} \\
& { }_{1} D^{2}+{ }_{1} T^{3} \rightarrow{ }_{2} \mathrm{He}^{4}(3.52)+{ }_{0} n^{1}(14.06)+17.58 \mathrm{MeV} \\
& \overline{5_{1} \mathrm{D}^{2} \rightarrow{ }_{1} \mathrm{H}^{1}+{ }_{2} \mathrm{He}^{3}+{ }_{2} \mathrm{He}^{4}+2{ }_{0} n^{1}+24.89 \mathrm{MeV}}
\end{aligned}
$$

In this case, there would be no need to breed tritium, and the lithium can be replaced by $\mathrm{Na}$ in a molten salt with the following composition:

$$
\mathrm{NaF} \cdot \mathrm{BeF}_{2} \cdot \mathrm{ThF}_{4}
$$

With a density and percentage molecular composition of:

$$
\rho=4.52 \frac{g m}{\mathrm{~cm}^{3}},(71-2-27 \mathrm{~mol} \%)
$$




\section{Fission-fusion hybrid molten salt breeder}

A system consisting of fusion fuel factories using DT or Catalyzed DD fusion and fission satellites receiving the bred fissile fuel for burning is shown in Fig. 9.

A one dimensional calculational model considers a plasma cavity with a $150 \mathrm{~cm}$ radius. The plasma neutron source is uniformly distributed in the central $100 \mathrm{~cm}$ radial zone and is isolated from the first structural wall by a $50 \mathrm{~cm}$ vacuum zone.

The blanket module consists of a $1 \mathrm{~cm}$ thick Type 316 stanless steel first structural wall that is cooled by a $0.5 \mathrm{~cm}$ thick water channel, a $42 \mathrm{~cm}$ thick molten salt filled energy absorbing and breeding compartment, and a $40 \mathrm{~cm}$ thick graphite neutron reflector.

The molten salt and graphite are contained within $1 \mathrm{~cm}$ thick Type 316 stainless steel structural shells

Computations were conducted using the one dimensional Discrete Ordinates transport ANISN code with a $P_{3}$ Legendre expansion and an $S_{12}$ angular quadrature.

The catalyzed DD system exhibits a fissile nuclide production rate of $0.880 \mathrm{Th}(\mathrm{n}, \mathrm{\gamma})$ reactions per fusion source neutron. The DT system, in addition to breeding tritium from lithium for the DT reaction yields $0.737 \mathrm{Th}(\mathrm{n}, \mathrm{\gamma})$ breeding reactions per fusion source neutron.

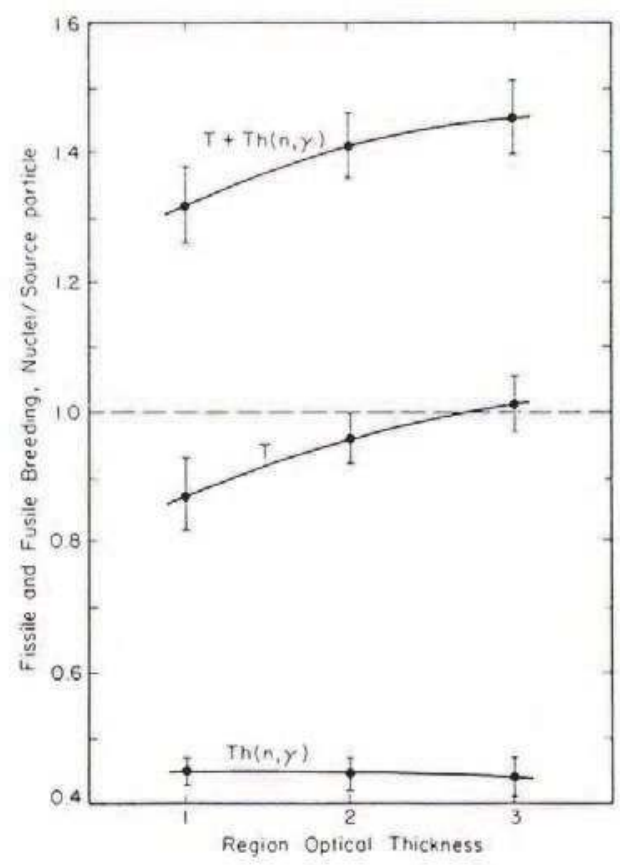

Fig. 10. Optimization of fissile $\mathrm{U}^{233}$ and fusile tritium (T) breeding.

Even though both approaches provide substantial energy amplification through the fusionfission coupling process, the DT system possesses marginal tritium breeding in the fusion island of 0.467 triton per source neutron and would need supplemental breeding in the fission satellites to reach a value of unity. 
The largest $\operatorname{Th}(\mathrm{n}, \mathrm{\gamma})$ reaction rate $(0.966)$ occurs when the sodium salt is used in conjunction with the DT reaction. For this case, however, the tritium required to fuel the plasma must be supplied to the system, since that produced in the blanket would be negligible $\left(3.18 \times 10^{-3}\right)$. A system of such kind has been proposed and studied by Blinken and Novikov.

A catalyzed or semi-catalyzed DD fusion cycle will not need tritium breeding. Both the DT and Catalyzed DD approaches provide substantial energy amplification through the fusionfission coupling process. However, the DT system possesses marginal tritium breeding in the fusion island and would need supplemental breeding in the fission satellites to reach a value of the tritium breeding ratio unity.

As a first generation cycle, a DT fusion cycle needs serious consideration of its tritium breeding potential. Enhancement of the fusile breeding would require the use of neutron multipliers and optimized flux trap geometrical configurations.

\section{Discussion}

Thorium supplies constitute a yet unused energy resource (Taylor, 1964). They occur primarily in the rare earth ore mineral Monazite and the thorium mineral thorite. The size of the global resource is estimated at $1.3 \times 10^{6}$ metric tonnes of $\mathrm{ThO}_{2}$. The USA and Australia hold the world's largest known reserves with uncertain estimates ranging from $0.19 \times 10^{6}$ $0.44 \times 10^{6}$ metric tonnes of $\mathrm{ThO}_{2}$. Many of the USA reserves sizes are not known, as a result of unavailable data for lack of economical extraction attractiveness without an energy use option for thorium.

The main international rare earths processors presently opt to process only thorium-free feed materials to avoid its radioactive content, even though they still have to cope with the radioactive isotope $\mathrm{Ce}^{142}$ which occurs in cerium. This has been negative for the low-cost monazite ores and other thorium bearing ores. This could change in the future if thorium is adopted as a byproduct for energy use. Supplies of rare earth elements are globally available in the international trade pipeline from diverse sources without discerned immediate shortages or bottlenecks.

Thorium occurs associated with uranium in some ores such as Thorite (Th, $\mathrm{U}) \mathrm{SiO}_{4}$ and, if exploited, would help expand the known U resource base.

Other ores are associated with rare earth elements or lanthanides such as monazite $(\mathrm{Ce}$, $\mathrm{La}, \mathrm{Y}, \mathrm{Th}) \mathrm{PO}_{4}$ which also contain other economically significant metal occurrences such as yttrium. In this case, Th as a fuel resource could be extracted for future energy applications as a byproduct of the other more important rare earth elements extraction process until such time when primary Th ores such as thorite and monazite would be exploited.

Four approaches to a thorium reactor are under consideration:

1. Use of a liquid molten Th fluoride salt,

2. Use of a pebble bed graphite moderated and He gas cooled reactor,

3. The use of a seed and blanket solid fuel with a Light Water Reactor (LWR) cycle,

4. A driven system using fusion or accelerator generated neutrons.

A concern is the potential risks to sustained economical development and of conflicts, both domestic and international, over the distribution of ever scarcer and more expensive resources. A pessimistic view maintains that the available resources cannot keep up with population and income growth, resulting in poverty and conflict for access to them. The optimistic view is that the market incentives will spur the birth of new approaches and solutions. The flaring of the first and second Gulf Wars had an element of the control of the 
Middle Eastern petroleum resources. Earlier, an oil embargo of Japan by the USA was followed two months later by the attack on Pearl Harbor.

The sober way to deal with temporary resource shortages is to wait long enough for the price increases to encourage the development of new resources and/or substitutes.

The Station Blackout accident, caused by a combined earthquake and tsunami event at the Fukushima Daiichi reactors on March 11, 2011 will lead to a reconsideration of the relative advantages and disadvantages of the existing $\mathrm{U}^{238-} \mathrm{Pu}^{239}$ fuel cycle against the alternative Th232-U233 fuel cycle.

\section{References}

H. A. Bethe, “The Fusion Hybrid," Nucl. News, Vol. 21, 7, 41, May 1978.

S. S. Rozhkov and G. E. Shatalov, "Thorium in the Blanket of a Hybrid Thermonuclear Reactor," Proc. U.S.-USSR Symp. Fusion-Fission Reactors, July 13-16, 1976, CONF760733, p. 143, 1976.

V. L. Blinkin and V. M. Novikov, "Symbiotic System of a Fusion and Fission Reactor with Very Simple Fuel Reprocessing," Nucl. Fusion, Vol. 18, 7, 1978.

Jungmin Kang and Frank N. von Hippel, "U-232 and the Proliferation Resistance of U-233 in Spent Fuel," Science and Global Security, Volume 9, pp. 1-32, 2001.

M. M. H. Ragheb, R. T. Santoro, J. M. Barnes, and M. J. Saltmarsh, "Nuclear Performance of Molten Salt Fusion-Fission Symbiotic Systems for Catalyzed Deuterium and Deuterium-Tritium Reactors," Nuclear Technology, Vol. 48, pp. 216-232, May 1980.

M. Ragheb, "Optimized Fissile and Fusile Breeding in a Laser-Fusion Fissile-Enrichment Flux Trap Blanket," Journal of Fusion Energy, Vol. 1, No.1, pp.285-298, 1981.

M. M. H. Ragheb, G. A Moses, and C. W. Maynard, "Pellet and Pellet-Blanket neutronics and Photonics for Electron Beam Fusion," Nucl. Technol., Vol. 48:16, April 1980.

M. Ragheb and S. Behtash, "Symbiosis of Coupled Systems of Fusion D-3He Satellites and Tritium and He3 Generators," Nuclear Science and Engineering, Vol. 88, pp. 16-36, 1984.

M. Ragheb and C. W. Maynard, "On a Nonproliferation Aspect of the Presence of U232 in the U233 fuel cycle," Atomkernenergie, 1979.

M. M. H. Ragheb, M. Z. Youssef, S. I. Abdel-Khalik, and C. W. Maynard, "ThreeDimensional Lattice Calculations for a Laser-Fusion Fissile Enrichment Fuel Factory," Trans. Am. Nucl. Soc., Vol. 30, 59, 1978.

M. M. H. Ragheb, S. I. Abdel-Khalik, M. Youssef, and C. W. Maynard, "Lattice Calculations and Three-Dimensional Effects in a Laser Fusion-Fission Reactor," Nucl. Technol. Vol. 45, 140, 1979.

J. A. Maniscalco, L. F. Hansen, and W. O. Allen, "Scoping Studies of U233 breeding fusion fission hybrid," UCRL-80585, Lawrence Livermore Laboratory, 1978.

L. M. Lidsky, "Fission-fusion Systems: Hybrid, Symbiotic and Augean," Nucl. Fusion, Vol. $15,1975$.

J. D. Lee, “The Beryllium/molten salt blanket-a new concept," UCRL-80585, Lawrence Livermore Laboratory, 1979.

M. M. H. Ragheb and C. W. Maynard, "Three-dimensional cell calculations for a fusion reactor gas-cooled solid blanket," Atomkernenergie (ATKE) Bd. 32, Lfg. 3, 159, 1978. 
James B. Hedrick, "Thorium in the United States," "1st Thorium Energy Alliance Conference, The Future Thorium Energy Economy," Kellog Conference Center, Gallaudet University, Washington D. C. 2002-3695, USA, October 19-20, 2009.

Robert Hargraves, "Aim High," "1st Thorium Energy Alliance Conference, The Future Thorium Energy Economy," Kellog Conference Center, Gallaudet University, Washington D. C. 2002-3695, USA, October 19-20, 2009.

Bradley S. Van Gosen, Virginia S. Gillerman and Theodore J. Armbrustmacher, "Thoriun Resources of the United States-Energy Resources for the Future?" Circular 1336, USA Geological Survey, USGS, Reston, Virginia, 2009.

Magdi Ragheb, "Nuclear Age Elements," in: "Nuclear, Plasma and Radiation Science, Inventing the Future,"

https://netfiles.uiuc.edu/mragheb/www, 2010.

Magdi Ragheb, "Uranium Resources in Phosphate Rocks," in: "Nuclear, Plasma and Radiation Science, Inventing the Future," https://netfiles.uiuc.edu/mragheb/www, 2010.

WNA, World Nuclear Association, "Thorium," http://www.world-nuclear.org/info/inf62.html, 2009.

James B. Hedrick, “2007 Minerals Yearbook,” USGS, September 2009.

Jungmin Kang and Frank N. von Hippel, "U-232 and the Proliferation Resistance of U-233 in Spent Fuel," Science and Global Security, Volume 9, pp. 1-32, 2001.

Magdi Ragheb, "The Global Status of Nuclear Power," in: "Nuclear, Plasma and Radiation Science, Inventing the Future," https://netfiles.uiuc.edu/mragheb/www, 2010.

S. R. Taylor, "Abundances of Chemical Elements in the Continental Crust: a New Table," Geochim. Cosmochim. Acta, 28, 1273, 1964. 


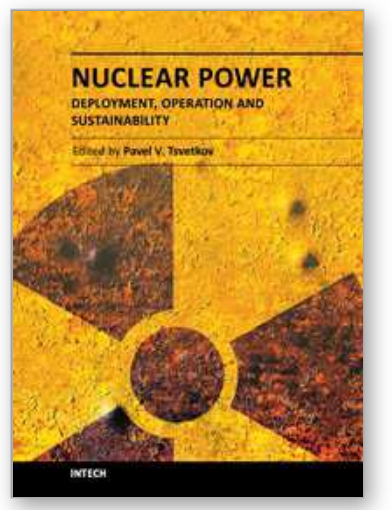

\author{
Nuclear Power - Deployment, Operation and Sustainability \\ Edited by Dr. Pavel Tsvetkov
}

ISBN 978-953-307-474-0

Hard cover, 510 pages

Publisher InTech

Published online 09, September, 2011

Published in print edition September, 2011

We are fortunate to live in incredibly exciting and incredibly challenging time. Energy demands due to economic growth and increasing population must be satisfied in a sustainable manner assuring inherent safety, efficiency and no or minimized environmental impact. These considerations are among the reasons that lead to serious interest in deploying nuclear power as a sustainable energy source. At the same time, catastrophic earthquake and tsunami events in Japan resulted in the nuclear accident that forced us to rethink our approach to nuclear safety, design requirements and facilitated growing interests in advanced nuclear energy systems. This book is one in a series of books on nuclear power published by InTech. It consists of six major sections housing twenty chapters on topics from the key subject areas pertinent to successful development, deployment and operation of nuclear power systems worldwide. The book targets everyone as its potential readership groups - students, researchers and practitioners - who are interested to learn about nuclear power.

\title{
How to reference
}

In order to correctly reference this scholarly work, feel free to copy and paste the following:

Magdi Ragheb (2011). Thorium Fission and Fission-Fusion Fuel Cycle, Nuclear Power - Deployment, Operation and Sustainability, Dr. Pavel Tsvetkov (Ed.), ISBN: 978-953-307-474-0, InTech, Available from: http://www.intechopen.com/books/nuclear-power-deployment-operation-and-sustainability/thorium-fission-andfission-fusion-fuel-cycle

\section{INTECH}

open science | open minds

\section{InTech Europe}

University Campus STeP Ri

Slavka Krautzeka 83/A

51000 Rijeka, Croatia

Phone: +385 (51) 770447

Fax: +385 (51) 686166

www.intechopen.com

\section{InTech China}

Unit 405, Office Block, Hotel Equatorial Shanghai

No.65, Yan An Road (West), Shanghai, 200040, China

中国上海市延安西路 65 号上海国际贵都大饭店办公楼 405 单元

Phone: +86-21-62489820

Fax: $+86-21-62489821$ 
(C) 2011 The Author(s). Licensee IntechOpen. This chapter is distributed under the terms of the Creative Commons Attribution-NonCommercialShareAlike-3.0 License, which permits use, distribution and reproduction for non-commercial purposes, provided the original is properly cited and derivative works building on this content are distributed under the same license. 